- Rodolfo Delfini Cançado

- Carlos Sérgio Chiattone

- Fausto Forin Alonso

- Dante Mário Langhi Júnior

- Rita de Cássia Silva Alves

\section{Iron deficiency in blood donors}

D iscipline of $\mathrm{H}$ ematology, D epartment of M edicine, Faculty of M ediml Sciences, Santa Casa de São Paulo, São Paulo, Brazil

See p. 131

ABSTRACT

CONTEXT: Blood donation results in a substantial loss of iron (200 to $250 \mathrm{mg}$ ) at each bleeding procedure $(425$ to $475 \mathrm{ml})$ and subsequent mobilization of iron from body stores. Recent reports have shown that body iron reserves generally are small and iron depletion is more frequent in blood donors than in non-donors.

OBJ ECTIVE: The aim of this study was to evaluate the frequency of iron deficiency in blood donors and to establish the frequency of iron deficiency in blood donors according to sex, whether they were first-time or multi-time donors, and the frequency of donations per year.

DESIGN: From September 20 to 0 ctober 5, 1999 three hundred blood donors from Santa Casa Hemocenter of São Paulo were studied.

DIAGNOSTIC TESTS: Using a combination of biochemical mea surements of iron status: serum iron, total iron-binding capacity, transferrin saturation index, serum ferritin and the erythrocyte indices.

RESULTS: The frequency of iron deficiency in blood donors was $11.0 \%$, of whom $5.5 \%(13 / 237)$ were male and $31.7 \%(20 / 63)$ female donors. The frequency of iron deficiency was higher in multi-time blood donors than in first-time blood donors, for male blood donors $(7.6 \%$ versus $0.0 \%, P<0.05)$ and female ones $(41.5 \%$ versus $18.5 \%, P<0.05)$. The frequency of iron deficiency found was higher among the male blood donors with three or more donations per year $(P<0.05)$ and among the female blood donors with two or more donations per year $(P<0.05)$

CONCLUSIONS: W e conclude that blood donation is a very important factor for iron deficiency in blood donors, particularly in multi-time donors and especially in female donors. The high frequency of blood donors with iron deficiency found in this study suggests a need for a more accurate laboratory trial, as hemoglobin or hematocrit measurement alone is not sufficient for detecting and excluding blood donors with iron deficiency without anemia.

KEY WORDS: Iron deficiency. Blood donor. Serum ferritin.

\section{........ INTRODUCTION}

The general impact of blood donation on iron status has been studied since the late 1970 's. ${ }^{1-5}$ Blood donation results in a substantial ( 200 to $250 \mathrm{mg}$ ) loss of iron at each bleeding procedure ( 425 to $475 \mathrm{ml}$ ) and subsequent mobilization of iron from body stores. Recent reportshaveshown that body iron reserves generally are small and iron depletion is more frequent in blood donors than in non-donors. ${ }^{4,6}$

An inverse correlation exists between body iron stores and absorbed iron. As body iron stores decrease, iron absorption increases. With continued iron loss, an individual either reaches equilibrium at a lower concentration of iron stores or becomesiron-depleted, eventually developing iron-deficient erythropoiesis and anemia. ${ }^{6}$

In the majority of blood banks, hemoglobin ( $\mathrm{H}$ b) and/or hematocrit measurements are used as a screening test for the ability to donate blood even though iron stores may be depleted in donors with $\mathrm{Hb}$ values abovethe arbitrarily defined limit for anemia. ${ }^{7}$

It is known that iron deficient anemia is the last stage of iron-deficiency and it is evident that hemoglobin measurement alone is inadequate for detecting blood donors with iron deficiency without anemia. ${ }^{8,9}$

Recent literature has suggested that serum ferritin levels appear to be a reliable indicator for body iron stores that can bemobilized and provide reliable measurements for determining iron deficiency at an early stage. Serum ferritin is directly proportional to body iron stores and concentration $\leq 12 \mathrm{ng} / \mathrm{ml}$ reflects an iron-depleted state. ${ }^{9-13}$
The aim of this study was to evaluate the frequency of iron deficiency in Santa Casa $\mathrm{H}$ emocenter blood donors and to establish the frequency of iron deficiency in blood donors according to sex, whether they were first-time or multi-time donors, and the blood donation frequency per year.

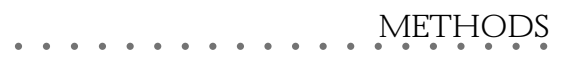

From September 20 to 0 ctober 5, 1999, three hundred blood donors werestudied using a combination of biochemical measures of iron status: serum iron (Bayer Company), total ironbinding capacity (TIBC) (Labtest Company), transferrin saturation index (TSI) [(serum iron/ CTLF) x100], serum ferritin (determined by the enzyme immunoassay method, Abbott Laboratories) and the erythrocyte indices (Cell-D yn, model 3000, Abbott Laboratories).

Approximately $450 \mathrm{ml}$ of blood was drawn at each phlebotomy and blood samples were taken at the end of the procedure.

According to the Brazilian Government requirement for blood donation ${ }^{14}$ weincluded in this study only donors with standard values of hemoglobin ( $\geq 12 \mathrm{~g} / \mathrm{dl}$ for women and $\geq 13 \mathrm{~g} / \mathrm{dl}$ for men) and/or hematocrit (38\% for women and $40 \%$ for men)

Iron-depleted donors were defined by se rum ferritin values below $12 \mathrm{ng} / \mathrm{ml}$ and TSI greater than or equal to $16 \%$; iron-deficient erythropoiesis when serum ferritin values were less than $12 \mathrm{ng} / \mathrm{ml}$ and TSI less than 16\%; and iron-deficiency anemia when serum ferritin values were less than $12 \mathrm{ng} / \mathrm{ml}$ and TSI less than $16 \%$, and hemoglobin less than 13 $\mathrm{g} / \mathrm{dl}$ (for men) or $12 \mathrm{~g} / \mathrm{dl}$ (for women). Iron 
deficiency includes iron-depleted donors and iron-deficient erythropoiesis donors.

In statistical analysis, differences wereevaluated by the M ann-W hitney rank sum test and the Student " $\mathrm{t}$ " test, and correlations using Spearman'srank correlation coefficient. ${ }^{15} \mathrm{~A}$ " $\mathrm{P}$ " value less than 0.05 was considered as statistically significant. All the statistical analyses were performed on the softwareSPSS, version PC + .

.................... RESTS

The characteristics of the 300 blood donors that werestudied weretheagein years(mean 33.0; median 32.0; range 18 to 60 ); the sex, with $79 \%$ being male (237/300); and the color, with 35\% being non-white (104/300). Thenumber of firsttime blood donors was 94 (31.3\%), and there were 206 (68.7\%) multi-time blood donors. Of the latter, $133(64.5 \%)$ were considered repeat donors (who had donated one or moretimes per year) and $73(35.5 \%)$ sporadic donors.

Thefrequency of iron deficiency in blood donors was $11.0 \%$, of whom $5.5 \%$ (13/237) were male and $31.7 \%$ (20/63) female donors. The frequency of iron deficiency was higher in multi-time blood donors than in first-time blood donors, for male blood donors (7.6\% versus $0 \%, \mathrm{P}<0.05)$ and female ones $(41.5 \%$ versus $18.5 \%, \mathrm{P}<0.05$ ) (Table 1 ).

Figures 1 and 2 show the mean ferritin se rum level observed in themaleand femaleblood donors, respectively, according to the blood donation frequency in the last 12 months.

The frequency of iron deficiency found was higher in the multi-time blood donors. This difference was statistically significant among the male blood donors with three or moredonations per year $(P<0.05)$ and among the female blood donors with two or more donations per year $(P<0.05)$ (Table 2$)$.

......... DISCUSSIO०

Iron is a vitally important element in human metabolism. It has a central role in erythropoiesis and is also involved in many other intracellular processes in all the tissues of the body. ${ }^{16,17}$

Thepotential for an individual donor to give blood without developing iron deficiency anemia displayed wide variation, probably due to differencesin nutritional iron intake, theprevalence of iron deficiency in the particular population, themenstrual iron lossin females, the frequency of blood donation and the use of supplemental iron, as well as the capacity to absorb iron. 5, 6, 18

Recent reportshaveshown that the frequency of iron deficiency is high in blood donors $(1.8 \%$

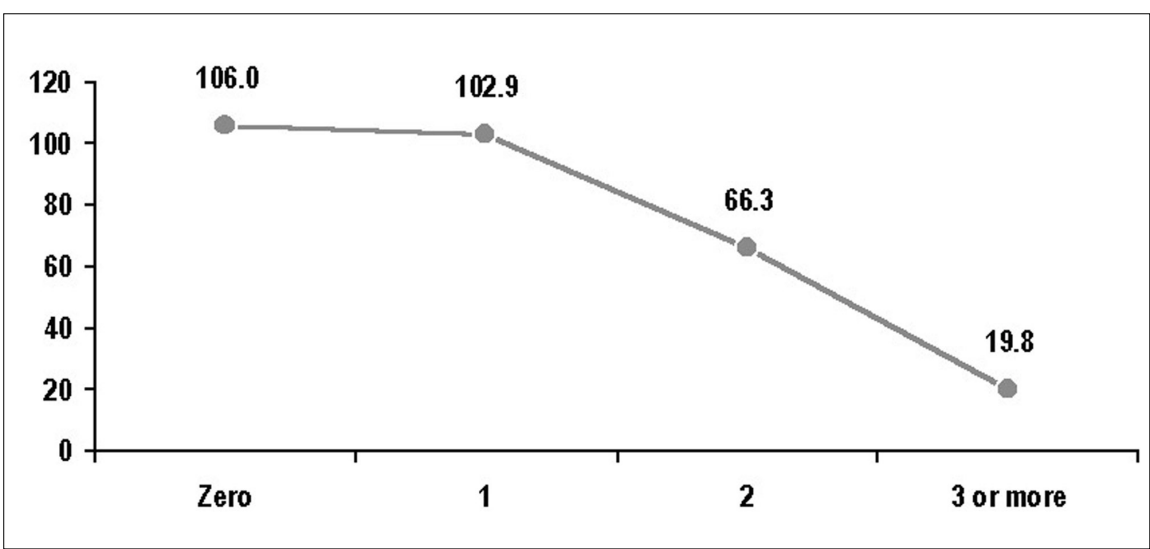

Figure 1. M ean ferritin serum level observed in the male blood donors according to the blood donation frequency in the las 12 months

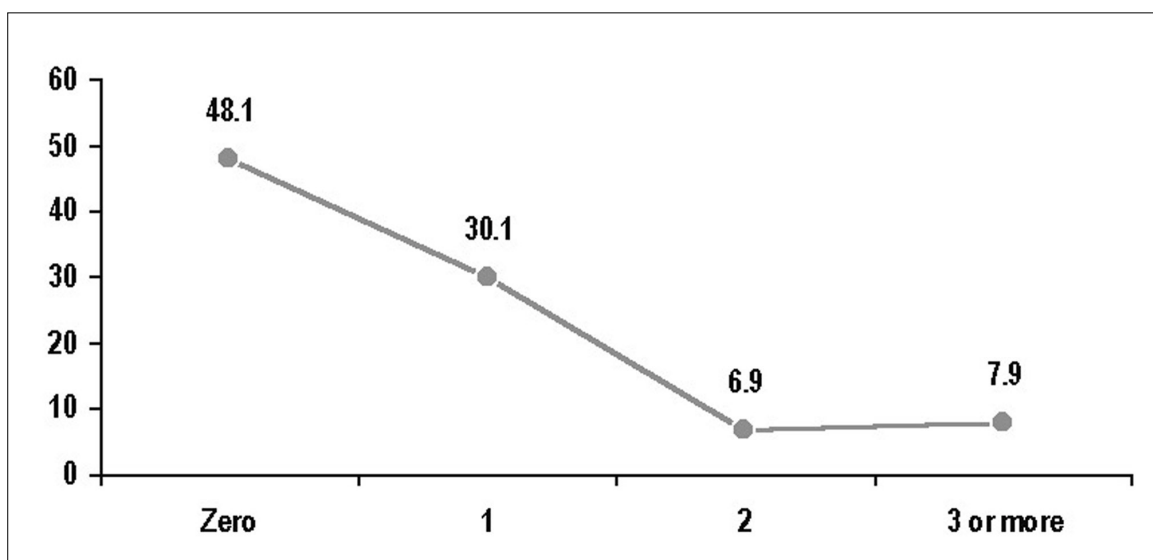

Figure 2. M ean feritin serum level observed in the female blood donors according to the blood donation frequency in the las 12 months.

\begin{tabular}{|c|c|c|c|c|}
\hline \multirow{2}{*}{$\begin{array}{l}\text { Sex } \\
\text { Type of Donor }\end{array}$} & \multicolumn{2}{|c|}{$\begin{array}{l}\text { Male } \\
n=237(79 \%)\end{array}$} & \multicolumn{2}{|c|}{$\begin{array}{l}\text { Female } \\
n=63(21 \%)\end{array}$} \\
\hline & $\begin{array}{l}\text { First-time } \\
(n=67)\end{array}$ & $\begin{array}{l}\text { Multi-time } \\
(n=170)\end{array}$ & $\begin{array}{l}\text { First-time } \\
(n=27)\end{array}$ & $\begin{array}{l}\text { Multi-time } \\
(n=36)\end{array}$ \\
\hline Iron Deficiency, n (\%) & $0(0.0)$ & $13(7.6) *$ & $5(18.5)$ & $15(41.5)^{*}$ \\
\hline No Iron Deficiency & $67(100.0)$ & $157(92.3)$ & $22(81.5)$ & $21(58.5)$ \\
\hline
\end{tabular}
$* P<0.05$.

Table 2. D istribution of serum ferritin, transferrin saturation index (T SI) and the frequency of iron deficiency in male blood donors according to the blood donation frequency in the last $\mathbf{1 2}$ months

\begin{tabular}{lllll}
$\begin{array}{l}\text { Blood Donation } \\
\text { Frequency in the } \\
\text { last } \mathbf{1 2} \text { months }\end{array}$ & $\mathbf{N}$ & $\begin{array}{l}\text { Male Blood } \\
\text { Donors: Iron } \\
\text { Deficiency } \mathbf{n}(\%)\end{array}$ & $\mathbf{N}$ & $\begin{array}{l}\text { Female Blood } \\
\text { Donors: Iron } \\
\text { Deficiency } \mathbf{n}(\%)\end{array}$ \\
\hline & & & & \\
\hline Zero & 127 & $1(0.8)$ & 9 & $9(22.5)$ \\
\hline 1 & 94 & $2(2.1)$ & 7 & $7(36.9)^{*}$ \\
\hline 2 & 15 & $9(60.0)^{*}$ & 2 & $2(100.0)$ \\
\hline 33 & 1 & $1(100.0)$ & 2 & $2(100.0)$ \\
\hline Total & $\mathbf{2 3 7}$ & $\mathbf{1 3 ( 5 . 5 )}$ & $\mathbf{6 3}$ & $\mathbf{2 0}(\mathbf{3 1 . 7})$ \\
\hline$N=$ number of blood donors in each group: (*) $P<0.05^{*}$ & & &
\end{tabular}


to $8.4 \%$ in malesand $4.5 \%$ to $34.8 \%$ in females), and more dependent on the frequency of dona tions than on the accumulated number of donations, $5,6,18-24$ as wealso found in thepresent study.

The only known significant disadvantage of blood donation isthe potential risk for iron deficiency. Therefore it seems reasonable to secure adequate iron reserves in the donor population in order to maintain an appropri- ate donation potential and to avoid possible non-hematological side effects of iron deficiency, i.e. changes in immune function, energy metabolism and work performance., ${ }^{8,19}$<smiles>CC(=O)NCC(=O)O[AsH3]</smiles>

We conclude that blood donation has a profound influenceon iron stores and isa very important factor for iron deficiency in blood donors, particularly in multi-timedonorsand, especially in female donors. The high frequency of blood donors with iron deficiency found in this study suggests a need for a more accurate laboratory trial, sincehemoglobin or hematocrit measurement aloneis not sufficient for detecting and excluding blood donors with iron deficiency without anemia.
1. Lieden G. Iron state in regular blood donors. Scand J H aematol 1973;11342-9.

2. Finch CA, C ook JD, LabbeRF, Cuala M. Effect of blood donation on iron stores as evaluated by serum ferritin. Blood 1977;50:441-7.

3. Skikne BS, Cook JD. Serum ferritin in the evaluation of iron status. Lab. M anagement 1981;19:31-5.

4. Agha F, Khan RA. Ferritin levels in professional blood donors. JAM A 1989;39:124-6.

5. M ilman N, Kirchhoff M. Influence of blood donation on iron stores assessed by serum ferritin and haemoglobin in a population survey of 1433 D anish males. Eur J H aematol 1991;47:134-9.

6. M ilman N , Sondergaard M . Iron stores in male blood donors evaluated by serum ferritin. Transfusion 1984;24:464-8.

7. Chueca M P, Galar GM , Ardanaz M F, Zabalegui A, M uruzábal L, M unhoz A. Lahemoglobina en la selección dehemodonación. Sangre 1995;1:41-4

8. Baynes RD . Iron deficiency. In: Brock JH , H alliday JW, Pippard MJ, Powell LW. Iron metabolism in health disease. London: WB Saunders; 1994:189-225.

9. Worwood M . Laboratory determination of iron status. In: Brock JH, H alliday JW, Pippard MJ, Powell LW, editors. Iron me tabolism in health and disease. London: W B Saunders; 1994:449-76.

\section{Publ ish ing infor mation}

Rodolfo Delfini Cançado, MD. Hematology and Hemotherapy Department. Faculty of Medical Sciences, Santa Casa de São Paulo, São Paulo, Brazil.

Carlos Sérgio Chiattone, MD. Head of Hematology and Hemotherapy Department, Faculty of Medical Sciences, Santa Casa de São Paulo, São Paulo, Brazil.

Fausto Forin Alonso, MD. Dermatology Department. Fac ulty of M edical Sciences, Santa Casa de São Paulo, São Paulo, Brazil.

Dante Mário Langhi Júnior, MD. Hematology and Hemotherapy Department. Faculty of Medical Sciences, Santa Casa de São Paulo, São Paulo, Brazil.

Rita de Cássia Silva Alves, MD. Hematology and Hemotherapy Department. Faculty of Medical Sciences, Santa Casa de São Paulo, São Paulo, Brazil.

Sources of funding: $\mathrm{N}$ ot declared

Conflict of interest: $\mathrm{N}$ ot declared

Last received: 03 A pril 2001

Accepted: 03 May 2001

Address for correspondence

Rodolfo Delfini Cançado

Hemocentro da Santa Casa de São Paulo

Rua Marquês de ltú, 579 - 2andar

São Paulo/ SP - Brazil - CEP 01223-001

E-mail: rdcan@uol.com.br
10. Addison GM, Beamish M R, H ales CN . An immunoradiometric assay for ferritin in the serum of normal subjects and patients with iron deficiency and iron overload. J Clin Pathol 1972;25:326-9.

11. M iles LEM , Lipschitz D A, Bieber CP, C ook JD. M easurement of serum ferritin by a 2-site immunoradiometric assay. Anal Biochem 1974;61:209-24.

12. Cook JD, Lipschitz D A, M iles LA, Finch CA. Serum ferritin as a measure of iron stores in normal subjects. Am J Clin Nutr 1974; 27:681-8

13. Lipschitz D A, C ook JD, Finch CA. A clinical evaluation of ferritin as an index on iron store. N Engl J M ed 1974; 290:1213-6.

14. Brasil. M inistério da Saúde. Gabinete do M inistro. - Portaria n. 1376 de 19 de novembro de 1993. A prova alterações na Portarian. 721/G M , de 09.08.89, que aprova N ormas T écnicas para coleta, processamento etransfusão de sangue, componentes e derivados, e dá outras providências. Diário O ficial da União, Braślia, 2 dez. 1993. Seção 1, p.18405.

15. Rosner B. Fundamentals of biostatistics. $2^{\text {nd }}$ ed. Boston: PWS Publishers; 1986:682

16. Aisen P. Current concepts in iron metabolism. Clin $\mathrm{H}$ aematol 1982;11:241-57

17. Brittenham GM . D isorders of iron metabolism: deficiency and overload. In: H offman R, Bens E, Shatiil S, Furie B, Choen H editors. $\mathrm{H}$ ematology: basic principles and practice. $\mathrm{N}$ ew York:

Churchill Livingstone; 1991:327-49.

18. Jacob RA, Sandstead HH, Klevay LM, Johnson LK. Utility of serum ferritin as a measure of iron deficiency in normal males undergoing repetitive phlebotomy. Blood 1980;56:786-91

19. Guerra CCC. Carência de ferro. Bol Soc $\mathrm{H}$ emato 1988;10:88:91.

20. Romero M S, Puente F, Abós M D , G utiérrez M . Incidencia de ferropenia en un colectivo de 922 candidatos altruistas donantes de sangre. Sangre 1989;34:126-9.

21. LamasM C, Pérez-LanzacJCL, Arrojo IP, Gordo RS, Christensen $E A$, Font ES. D eterminación deferritina sérica: Consideraciones para evitar ferropenia inducida en donantes de sangre. Sangre, 39:9-14, 1994

22. M ilman N, Pedersen N S, Visfeldt J. Serum ferritin concentra tions and iron storesin normal subjects. Serum ferritin in healthy $D$ anes: relation to marrow haemosiderin iron stores. $D$ an $M$ ed Bull 1983;30:115-20.

23. Gualandro SFM , Cliquet M G Silveira PAA, et al. D eficiência de ferro em doadoras de sangue da Fundação Pró-sangue/ Hemocentro de São Paulo. Ser M onogr Esc Bras Hematol 1999;6(suppl):8. [Resumo]

24. Birgegard G, H ogman C, Killander A, Wide L. Serum ferritin levels in male blood donors. Relation to number of phlebotomies and iron supplementation. Vox Sang 1978;34:65-70.
IN TRO D U ÇÃO: A doação de sangue causa redução substancial na quantidade de ferro do organismo (cada unidade de sangue retirada [425 a 475 ml] contém 200 a 250 mg deferro) com conseqüente mobilização do ferro de depósito. Recentes estudos têm demonstrado que as reservas de ferro do organismo são pequenas, e sua deficiência é mais freqüente nos doadores de sangue que nos indivíduos não-doadores de sangue.

OBJET IVO: Avaliar a freqüência da deficiência de ferro em doadores de sangue do $\mathrm{H}$ emocentro da Santa C asa de São Paulo segundo o sexo, 0 tipo de doador e a freqüência de doações realizadas nos últimos 12 meses.

LO CAL: H emocentro da Santa Casa de São Paulo.

PARTICIPANTES: No período de 20 de setembro a 5 de outubro de 1999 foram estudados 300 doadores de sangue.

TEST ES D IAG N ÓST IC O S: U tilizamos a determinação das dosagens do ferro sérico, da capacidade total de ligação do ferro, do índice de saturação da transferrina, da ferritina sérica e dos índices eritrocitários.

RESULTAD O S: A freqüência dedoadores desangue queapresentavam deficiência deferro observada foi de $11,0 \%(33 / 300)$, sendo $5,5 \%(13 / 237)$

\section{RESUMO}

nos doadores do sexo masculino e de $31,7 \%$ (20/63) nos doadores do sexo feminino. Paraas mulheres, $18,5 \%$ delas já apresentavam deficiência deferro à primeira doação desangue, epara as doadoras freqüentesfoi $41,5 \%$. Entre os homens, nenhum doador apresentava deficiência deferro à primeira doação desangue e, para os doadores freqüentes, a deficiência de ferro foi de 7,6\%. A freqüência observada foi maior para os doadores com três ou mais doaçõesnosúltimos 12 meses $(P<0,05)$ epara as doadoras com duas ou mais doações nos últimos 12 meses $(P<0,05)$.

CON CLUSÕ ES: A doação de sangue constituise numa causa importante de deficiência de ferro em doadores de sangue, particularmente nos doadores freqüentes do sexo feminino. A elevada freqüência de doadores de sangue com deficiência de ferro observada nesse estudo sugere a necessidade de uma triagem laboratorial mais acurada, uma vez que a determinação isolada da hemoglobina ou do hematócrito não é suficiente para detectar e excluir os doadores com deficiência de ferro ainda sem anemia.

PALAVRAS-CH AVE: D eficiência de ferro. D oador de sangue. Ferritina sérica. 